Proc. Indian Acad. Sci., Vol. 85 B, No. 6, 1977, pp. 407-411.

\title{
Environmental restraints on the food intake, growth and conversion efficiency of Gambusia affinis: influence of Living space
}

\author{
Katre Shakuntala and S. RavichandRa RedDy \\ Department of Zoology, Bangalore University, Bangalore 560001 \\ MS received 3 January 1977; in revised Form 25 February 1977
}

\begin{abstract}
ABSTRAC1
Food intake, growth and conversion efficiency of juvenile Gambusia affinis are considerably influenced by the volume of watcr available per fish. On an 'ad libitum' diet of Tubifex tubifex worms, juveniles reared in intermediate amounts of "living space" of 500 and $800 \mathrm{ml}$ water per 4 individuals, exhibited maximum growth and conversion efficiency. Both below and beyond these volumes of water, the above parameters decreased indicating the inhibitory influence of 'limited' as well as 'abundant' living space on the food conversion of the fish.
\end{abstract}

\section{INTRODUCTION}

THE normal phenotype of an organism is the result of continuous interactions between the genotype and the environment in which it develops. ${ }^{1}$ Growth is gene:ally viewed as a 'wide spectrum indicator', reflecting the net stress effects of environmental conditions on the metabolic processes of the fish. ${ }^{2}$ As the food intake, growth and conversion efficiency of fish are controlled by intiinsic as well as extrinsic factors, ${ }^{3}$ a comprehensive understanding of the organism's capabilities within the environmental confines condusive to growth, is an essential prerequisite for the management of fish resource. ${ }^{4}$

In the larvivorous fish Gambusia affinis the intrinsic factors like body weight and age are known to considerably influence its food intake, growth and conversion efficiency. ${ }^{5}$ The present paper deals with the laboratory studies of environmental restraints on these parameters of G. affinis. An investigative study of this kind may aid in a meaningful interpretation of the influence of environment on the 'ecological success' of this widespread mosquito fish. 


\section{Materials and Methods}

Gestating female Gambusia affinis were collected from a local fish farm and reared in the laboratory on Oligochaete worms. For each series of feeding experiments, healthy juveniles born of single fish were chosen by random selection and divided into six groups, each with four juveniles. These juveniles were maintained in $200,250,500,800,1000$ and $1600 \mathrm{ml}$ of water respectively in aquaria (surface area $314 \mathrm{~cm}^{2}$ ) at $24 \pm 1^{\circ} \mathrm{C}$.

In nature, the fish is known to feed on mosquito larvae, ${ }^{9}$ the other items of its food being Chironomid larvae, tadpoles, small crustaceans, worms and dead fish rot.7 For the present study, the Oligochaete worm Tubifex tubifex was chosen for two reasons: The worms are known to be highly nutritive ${ }^{8}$ and easily digested by fish. ${ }^{9}$ Further, these worms tend to remain clustered at the floor of the aquaria and the predatory fish does not incur any energy expenditure on prey searching and prey capture, both of which may alter the feeding behaviour, food intake as well as conversion efficiency of the fish. ${ }^{10,11}$

The experimental juveniles were fed 'ad libitum' on a diet of Tubifex worms for 30 days from the first day of their birth. At the end of the thirty days the juveniles were sacrificed and their average daily food intake (mg dry food consumed/fish/day), average daily growth (mg dry substance gained/ fish/day) and percentage conversion efficiency $\left[K_{1}=(\right.$ daily growth $(\mathrm{mg}) /$ daily food intake $(\mathrm{mg})) \times 100$ ] were calculated to determine the influence/ of the different volumes of waier, i.e., the amount of living space offered on the above parameters of the fish.

\section{Results AND Discussion}

Every organism requires a minimum amount of space within which it can carry on its necessary exchanges with the environment. ${ }^{12}$ For an aquatic organism, the 'space' factor can be altered in the following two ways :

1. While keeping the total volume of water in the aquaria constant, an alteration in the density (i.e., number of individuals) can be brought about. This leads to a conspecific crowding effect and is known to reduce growth in both amphibians and fishes. ${ }^{13-17}$ In fish, this reduction in growth is attributed to an increased accumulation of metabolic products (wastes and external metabolites) as well as increased activity of the fish. ${ }^{18}$

2. As in the present experiment, the density can be maintained at a constant while only the volume of water in the aquaria can be 
altered. Such increases in volume of water reduce the crowding effects as well as accumulation of waste products but provide increased 'living space' for the individual fish, both by an increase in the total space and depth of water column thus ensuring ample scope for enhanced swimming activity of the fish (see table 1).

Table 2 represents the food intake, growth and conversion efficiency of Gambusia affinis as influenced by the different volumes of water in which the fish was reared. From this table, it is seen that except for the slightly high value of daily food intake of $3.53 \mathrm{mg} /$ fish/day for juveniles reared in $200 \mathrm{ml} / \mathrm{fish}$, there was no marked difference. in the food intake of fish reared in other volumes of water. Both below and beyond a volume of $200 \mathrm{ml}$ water/fish the food intake values decreased indicating a peak feeding in this

Table 1. Gambusia affinis: Amount of water and "living space" available for individuals reared in different volumes of water.

\begin{tabular}{ccccc}
\hline \multicolumn{2}{c}{ Volume of water } & $\begin{array}{c}\text { Depth of } \\
\text { water column } \\
\text { (mm) }\end{array}$ & $\begin{array}{c}\text { Total swimming } \\
\text { space per fish } \\
\text { (ml) }\end{array}$ \\
\hline ml/4 fish & ml/fish & 50 & 8 & 200 \\
200 & $62 \cdot 5$ & 10 & 250 \\
500 & 125 & 20 & 500 \\
800 & 200 & 32 & 800 \\
1000 & 250 & 40 & 1000 \\
1600 & 400 & 64 & 1600 \\
\hline
\end{tabular}

Table 2. Gambusia affinis: Influence of "living space" on the food intake, growth and conversion efficiency of juveniles. Values represent the means of 12 individuals in three repeated series of experiments each with 4 juveniles.

\begin{tabular}{|c|c|c|c|}
\hline $\begin{array}{l}\text { "Living space" } \\
\text { offered } \\
\text { (ml/fish) }\end{array}$ & $\begin{array}{c}\text { Food intake } \\
\text { (mg dry food/fish/ } \\
\text { day) }\end{array}$ & $\begin{array}{c}\text { Growth } \\
\text { (gain in mg dry } \\
\text { substance/fish/day) }\end{array}$ & $\begin{array}{l}\text { Conversion } \\
\text { efficiency } \\
\left(\mathbf{K}_{1}: \%\right)\end{array}$ \\
\hline 50 & $2 \cdot 54 \pm 0 \cdot 46$ & $0.38 \pm 0.06$ & $14 \cdot 96 \pm 1 \cdot 30$ \\
\hline $62 \cdot 5$ & $2 \cdot 53 \pm 0 \cdot 12$ & $0.43 \pm 0.07$ & $16 \cdot 99 \pm 1 \cdot 93$ \\
\hline 125 & $2 \cdot 52 \pm 0 \cdot 16$ & $0.58 \pm 0.06$ & $23 \cdot 02 \pm 1 \cdot 02$ \\
\hline 200 & $3 \cdot 53 \pm 0 \cdot 41$ & $0 \cdot 57 \pm 0 \cdot 21$ & $16 \cdot 15 \pm 4 \cdot 63$ \\
\hline 250 & $2 \cdot 50 \pm 0 \cdot 12$ & $0.38 \pm 0.05$ & $15 \cdot 20 \pm 3 \cdot 72$ \\
\hline 400 & $2 \cdot 20 \pm 0.01$ & $0 \cdot 18 \pm 0.04$ & $8 \cdot 18 \pm 2 \cdot 02$ \\
\hline
\end{tabular}


intermediate 'living space'. Brown ${ }^{19}$ also reported that in Salmo trutta, fish reared in intermediate amounts of living space had the maximum appetites. During the present studies the least food intake value of $2.20 \mathrm{mg} /$ fish/day was obtained for a juvenile reared in $400 \mathrm{ml}$ of water/fish, thus indicating that a large 'living space' inhibits food intake in G. affiris.

Though juveniles of Gambusia affinis reared in $200 \mathrm{ml}$ water/fish exhibited maximum food intake, growth was observed to be maximum in fish reared in $125 \mathrm{ml}$ of water per fish $(0.58 \pm 0.06 \mathrm{mg} / \mathrm{fish} /$ day $)$ decreasing slightly to $0.57 \mathrm{mg} /$ fish/day for individuals reared in $200 \mathrm{ml}$ of water/fish, thus indicating that 125 to $200 \mathrm{ml}$ of water/fish provide the jdeal space for best growth of juveniles of G. affinis. Below and beyond these volumes of water again there was a reduction in the growth of the fish reaching the least value of $0.18 \mathrm{mg} /$ fish/day in fish reared in $400 \mathrm{ml}$ of water/individual. Trouts with much space are also reported to feed and grow erratically. ${ }^{19}$ In the medaka Oryzias latipes, Magnuson ${ }^{16}$ reported that decreasing the amount of space by four times did not affect the growth rate of fish, whereas increasing the population size 4 times markedly influenced the growth rate. In $G$. affinis however, even a reduction in the total volume of water to $62.5 \mathrm{ml} /$ fish from the ideal $125-200 \mathrm{ml} /$ fish, significantly reduced the growth rate. As the density of fish remained the same in the present experiments, reduction in the growth rate of fish in reduced space can be attributed to be a direct consequence of the limitation of the space.

The food conversion efficiency of juvenile Gambusia affinis was also seen to be highest in individuals held in $125 \mathrm{ml}$ of water/fish $(23.02 \pm 1.02)$ exhibiting decreases both below and beyond this volume of water. The least efficiency was exhibited by fish reared in $400 \mathrm{ml}$ of water $(8 \cdot 18 \pm 2 \cdot 02)$. Thus it appears that 125 to $200 \mathrm{ml}$ of water/fish (i.e., 500 to $800 \mathrm{ml}$ of water/ 4 fish) is the ideal 'living space' for juveniles of G. affinis to elaborate best growth and conversion efficiency.

\section{REFERENCES}

1. Needham, A. E., The grow th process in animals. London, Sir Issac Pitman. p. 522 (1964).

2. Webb, P. W. and Brett, J. R., J. Fish. Res. Bd. Canada 30. 499 (1973).

3. Pandian, T. J., Mechanisms of Heterotrophy, in: Marine Ecology, Vol. 11, Part 1. London, John Wiley \& Sons, 61 (1975).

4. Beamish, F. W. H., Niimi, A. J. and Lett, P. F. K. P., Comparative Physiology-Functional aspects of structural materials. North Holland Publishing Company (1975).

5. Katre, S. and Reddy, S. R., Hybrobiologia (in press).

6. Menon, M. D. and Chacko, P. I., Proc. Indopacific Fish. Council, Sec. 2,1 (1955).

7. Kalandadse, L. and Mtschedlidse, J., Arch. Schiffs-U. Trop. Hyg. 36539 (1932). 
8. Galinat, A., Pols. Arch. Hydrobiol. 8129 (1960).

9. Mann, H., Nahrtiere durch Verschiedene Fische. Z. Fisch. 33231 (1935).

10. Kerr, S. R., J. Fish. Res. Bd. Canada 28809 (1971).

11. Pandian, T.J. and Ponniah, A. G., Proc. Sem. Genetic studies of Mosquitoes, p. 29, Abstract (1976).

12. Clarke, C. L., Elements of Ecology, New York, John Wiley, pp. 560 (1954).

13. Richards, C. M., Physiol. Zool. 31138 (1958).

14. Licht, L. E., Ecology 48736 (1567).

15. Kawajiri, M., J. Imp. Fish. Inst. Tokyo 248 (1928).

16. Magnuson, J. J., Can. J. Zool. 40313 (1962).

17. Stewart, B. M. Growth 38219 (1974).

18. Kinne, O., Physiol. Zool. 33288 (1960).

19. Brown, M. E., The Physiology of fishes. Vol. 1, New York, Academic Press (1957). 